\title{
Numismatic and Archaeological Collecting in Northern Sicily during the First Half of the Nineteenth Century
}

Antonino Crisà

BAR International Series 2411 
Published by

Archaeopress

Publishers of British Archaeological Reports

Gordon House

276 Banbury Road

Oxford OX2 7ED

England

bar@archaeopress.com

www.archaeopress.com

BAR S2411

Numismatic and Archaeological Collecting in Northern Sicily during the First Half of the Nineteenth Century

(C) Archaeopress and A Crisà 2012

ISBN 9781407310091

Printed in England by Information Press, Oxford

All BAR titles are available from:

Hadrian Books Ltd

122 Banbury Road

Oxford

OX2 7BP

England

www.hadrianbooks.co.uk

The current BAR catalogue with details of all titles in print, prices and means of payment is available free from Hadrian Books or may be downloaded from www.archaeopress.com 


\section{Contents}

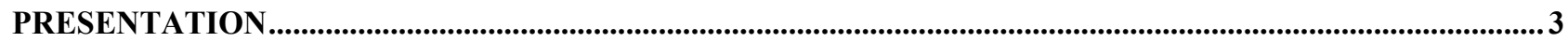

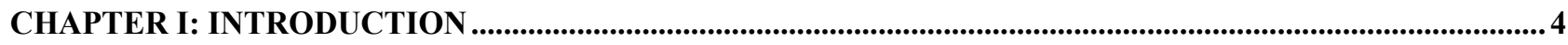

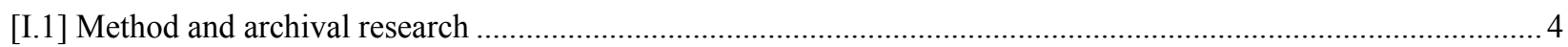

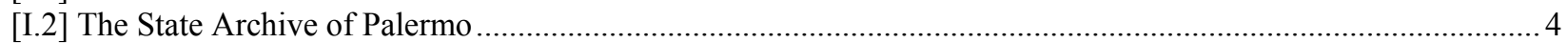

[I.3] The Archive of the Mandralisca Foundation in Cefalù ............................................................................ 4

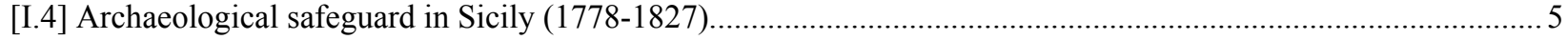

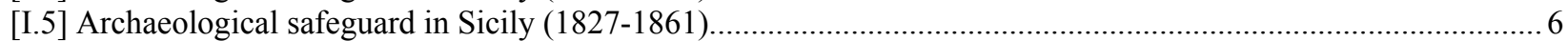

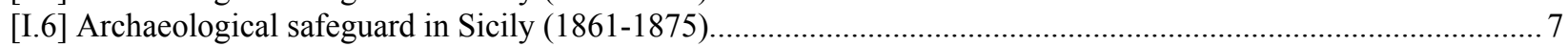

[I.7] Sicilian antiquarianism during the first half of the nineteenth century .................................................. 8

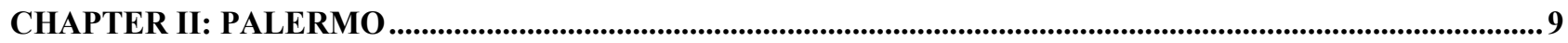

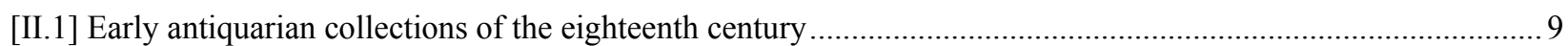

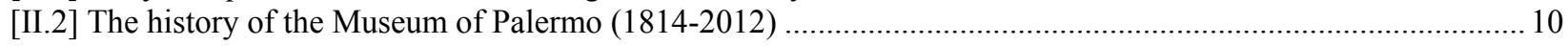

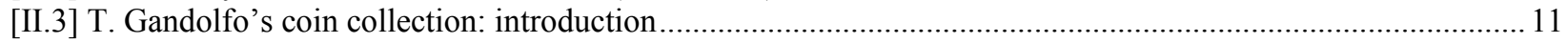

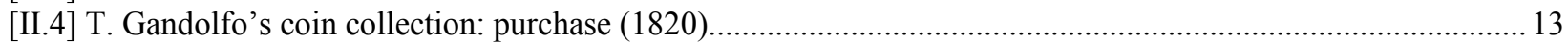

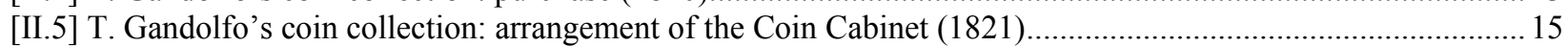

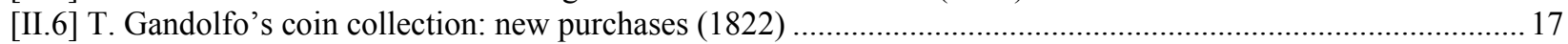

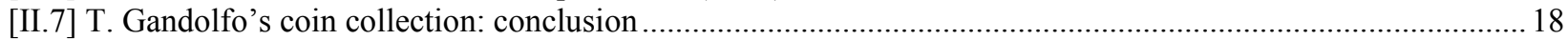

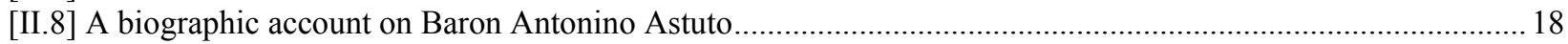

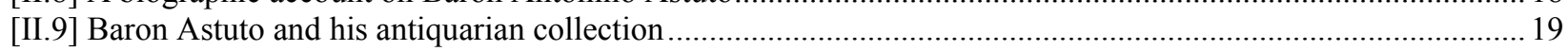

[II.10] Published documentation on Baron Astuto's collection .....................................................................20

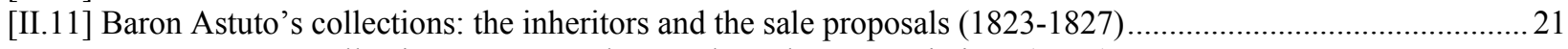

[II.12] Baron Astuto's collections: G. La Barbera and purchase negotiations (1858) ..........................................22

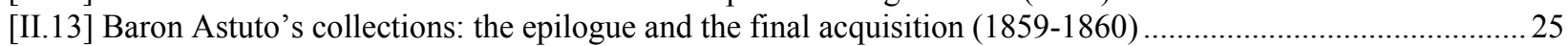

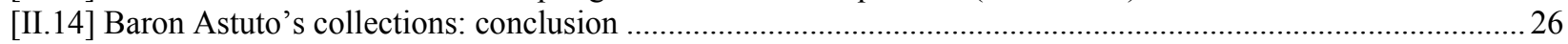

[II.15] Giarre (1832): ancient coins for the Museum of Palermo...................................................................2 27

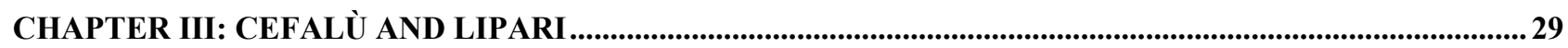

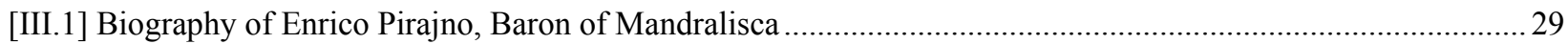

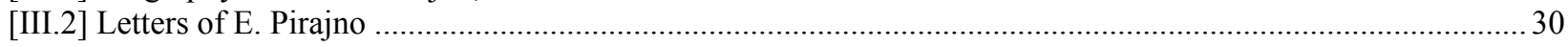

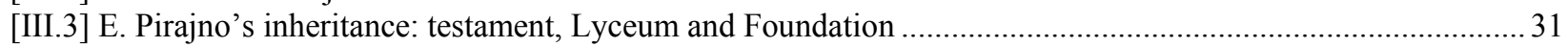

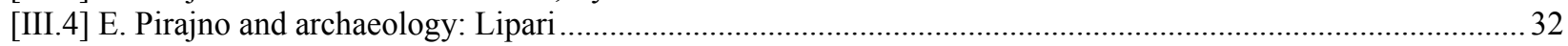

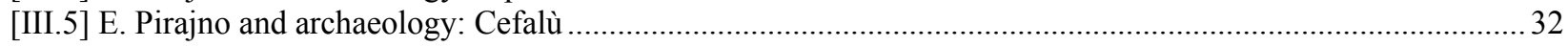

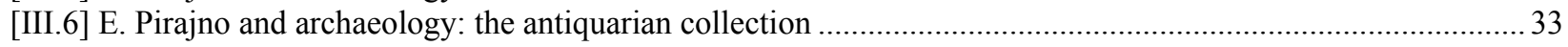

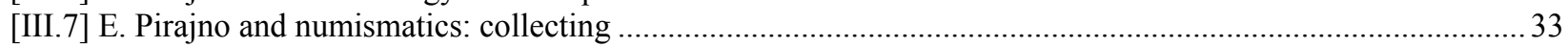

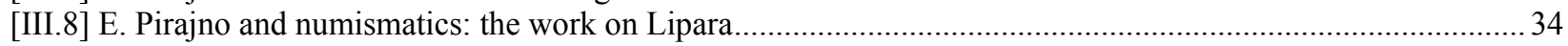

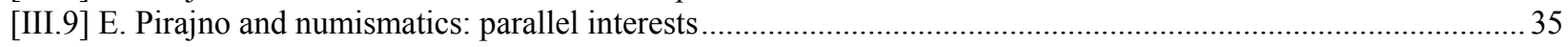

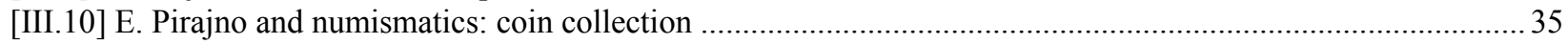

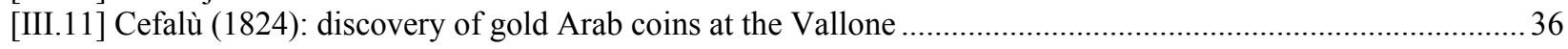

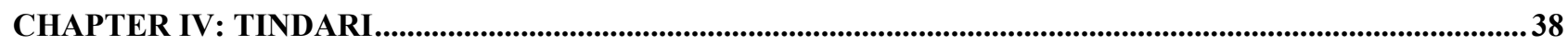

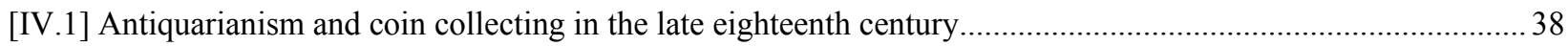

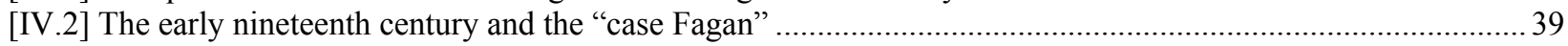

[IV.3] From the Commission's excavations to the Italian Unification ............................................................. 41

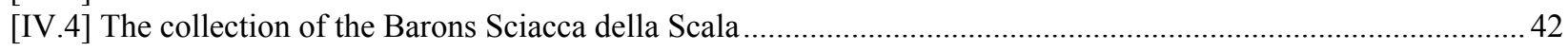

[IV.5] Research of Pirajno at Tindari: methods and edited documentation ...................................................... 43

[IV.6] Research of Pirajno at Tindari: archaeological finds .....................................................................44

[IV.7] Research of Pirajno at Tindari: numismatic finds and Agathyrnos .................................................... 44

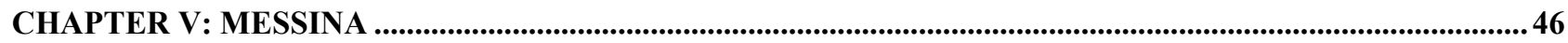

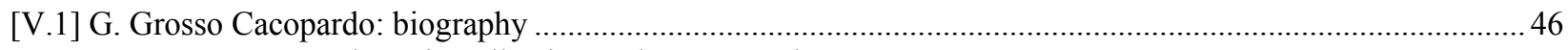

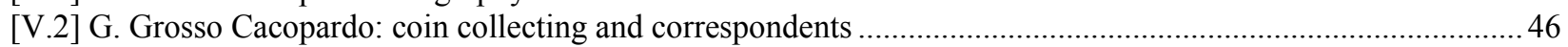

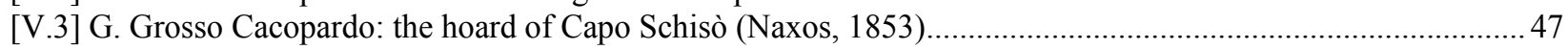

[V.4] G. Grosso Cacopardo: the numismatic collection ............................................................................ 48

[V.5] Messina (1845): export of ancient coins for the King of Bavaria..................................................... 49

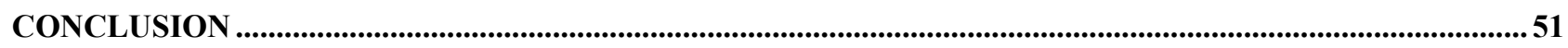

APPENDIX I: TOMMASO GANDOLFO'S COIN COLLECTION (1820-1822)............................................55 
APPENDIX II: ANTONINO ASTUTO'S ANTIQUARIAN COLLECTION (1823-1860)........................................89

APPENDIX III: GIARRE (1832): ANCIENT COINS FOR THE MUSEUM OF PALERMO ...............................113

APPENDIX IV: ENRICO PIRAJNO, BARON OF MANDRALISCA (1855-1926) ...................................................117

APPENDIX V: CEFALÙ (1824): DISCOVERY OF GOLD ARAB COINS AT THE VALLONE ........................ 120

APPENDIX VI: MESSINA (1845): EXPORT OF ANCIENT COINS FOR THE KING OF BAVARIA..............123

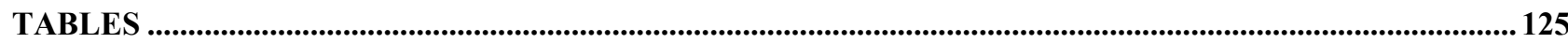

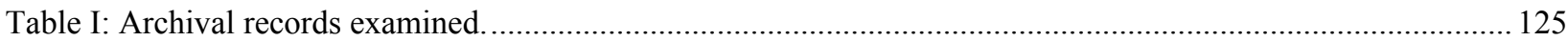

Table II: Coin hoards (province of Messina, first half of the nineteenth century).................................................. 126

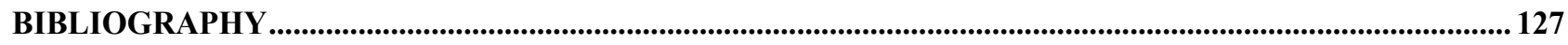

ABBREVIATIONS....................................................................................................................................................... 139

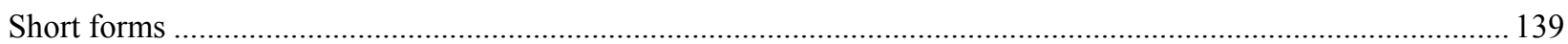

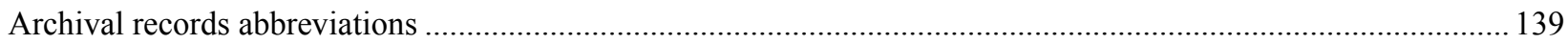

LIST OF OFFICES AND AUTHORITIES (ENGLISH-ITALIAN TRANSLATION),.......................................... 142

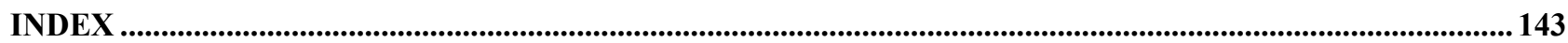

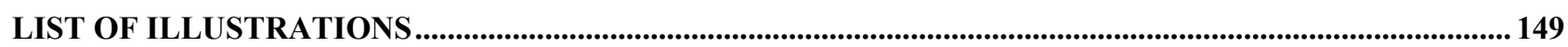

ILLUSTRATIONS ……....................................................................................................................................................... 150 